\title{
Inhibitory effect of PGF-2 $\alpha$ on hCG-stimulated progesterone production in vitro by luteal cells from guinea-pigs at different stages of the oestrous cycle
}

\author{
M. C. Richardson and M. J. Peddie* \\ Department of Human Reproduction and Obstetrics, University of Southampton, Princess Anne \\ Hospital, Coxford Road, Southampton SO9 4HA, and * Department of Physiology and \\ Pharmacology, School of Biochemical and Physiological Sciences, University of Southampton, \\ Bassett Crescent East, Southampton SO9 3TU, U.K.
}

\begin{abstract}
Summary. Suspensions of luteal cells were prepared by collagenase dispersion of guinea-pig corpora lutea obtained at specific times during the oestrous cycle. Luteal cells incubated with hCG produced increased amounts of progesterone. For Days 3-13 of the oestrous cycle, the concentrations of hCG required for $50 \%$ of the maximum response were within the range, $1 \times 10^{-3}$ to $7 \times 10^{-3} \mathrm{i} . \mathrm{u} . / \mathrm{ml}$, showing no marked loss of sensitivity to hCG with increasing luteal age. PGF- $2 \alpha(1 \mu \mathrm{mol} / \mathrm{l})$, had no effect on basal production of progesterone but significantly inhibited hCGstimulated progesterone production by luteal cells isolated on Days 7, 9, 10, 12 and 13 of the cycle. This concentration of PGF-2 $\alpha$ had no significant effect on progesterone production by luteal cells prepared earlier in the cycle (Days 3 and 5). It is concluded that (a) the luteolytic action of PGF- $2 \alpha$ in the guinea-pig is mediated, at least in part, by direct action on luteal cells, and (b) the cells from newly formed corpora lutea are resistant to the direct inhibitory action of PGF- $2 \alpha$.
\end{abstract}

\section{Introduction}

There is considerable evidence to support the concept that prostaglandin (PG) F-2 $\alpha$ is the uterine factor responsible for luteolysis in the guinea-pig (reviewed by Poyser, 1976). However, the luteolytic effect of PGF-2 $\alpha$ in the guinea-pig, well established in vivo (Blatchley \& Donovan, 1972; Dwyer \& Church, 1979), has not, hitherto, been investigated in vitro, where PGF-2 $\alpha$ may be added directly to suspensions of luteal cells.

In a number of species, newly formed corpora lutea have been shown to be refractory to the action of PGF-2 $\alpha$ in vivo (reviewed by Karim \& Hillier, 1979). Such an early resistance to prostaglandin has been observed in vivo in the guinea-pig (Tso \& Tam, 1977). If the effect of PGF-2 $\alpha$ in vitro were truly to reflect the action of this agent in vivo, luteal cells might be expected to differ in their response to PGF-2 $\alpha$ depending on the age of the corpora lutea from which they were prepared. Such a finding would also confirm the view that the effects of PGF- $2 \alpha$ measured in vitro are specific actions, requiring the same onset of responsiveness as that necessary for the initiation of luteolysis in vivo.

The present study was therefore undertaken to develop an in-vitro dispersed luteal cell system for the guinea-pig. Responses to a range of concentrations of hCG were measured at 
specific stages during the life-span of the corpus luteum and the effect of luteal age on the action of PGF- $2 \alpha$ was also investigated.

Part of this study has been published in preliminary form (Richardson \& Peddie, 1980).

\section{Materials and Methods}

\section{Animals}

Adult female guinea-pigs weighing 500-750 g were used. The animal house conditions and the method for monitoring oestrous cycles were as previously described (Peddie, 1980), the day of oestrus (designated as Day 1) being taken as the day on which maximum cornification of the vaginal epithelium was seen before the post-ovulatory influx of leucocytes.

\section{Preparation and incubation of cell suspensions}

Animals were anaesthetized with pentobarbitone sodium $(40 \mathrm{mg} / \mathrm{kg}$, i.p.) and then killed by cervical dislocation. The ovaries were removed and placed immediately in Dulbecco's modified Eagle's medium (Flow Laboratories, Irvine) containing glutamine $(0.584 \mathrm{~g} / \mathrm{l})$, sodium bicarbonate $(3.7 \mathrm{~g} / 1)$ and bovine serum albumin $(5 \mathrm{~g} / 1)$. Corpora lutea were then excised under a dissecting microscope. For each day of the oestrous cycle studied, 6-8 corpora lutea from two animals were pooled and then dissociated in medium containing collagenase according to a method previously described for the preparation of cell suspensions from biopsies of human corpus luteum (Richardson \& Masson, 1980). A sample of the dispersed cell preparation was examined under the light microscope and the cells were counted in the presence of methylene blue $\left(0.01 \%\right.$, w/v). Many of the cells (total yield, $\left.1-2 \times 10^{6}\right)$ remained in small clumps of about 5-20 cells. The viability of the dispersed cells was about $80 \%$ as judged by trypan blue exclusion (Tennant, 1964). No change in viability was noted after incubating the cells $\left(2 \mathrm{~h}, 37^{\circ} \mathrm{C}\right)$ in the presence or absence of PGF- $2 \alpha(1 \mu \mathrm{mol} / \mathrm{l})$.

Samples $(0.3 \mathrm{ml})$ of the final suspension, each containing about $3 \times 10^{4}$ cells, were incubated at $37^{\circ} \mathrm{C}$ for $2 \mathrm{~h}$ with various hormonal additions. A preparation of the 2nd International Standard for hCG (National Institute for Biological Standards and Control, Hampstead, London) was serially diluted in culture medium before addition to the cell suspension. Samples of a stock ethanolic solution of PGF-2 $\alpha$-tromethamine salt (donated by The Upjohn Co., Kalamazoo, Michigan, U.S.A.) were evaporated under nitrogen and then thoroughly dissolved in culture medium before addition. After incubation, the cell suspensions were stored frozen $\left(-20^{\circ} \mathrm{C}\right)$ before radioimmunoassay.

\section{Radioimmunoassay of progesterone}

Cell suspensions (cells with medium) were assayed for progesterone, after extraction with hexane, using the radioimmunoassay described by Richardson \& Masson (1980). The antiserum, raised in sheep against progesterone-11 $\alpha$-hemisuccinate-ovalbumin, was from Guildhay Antisera, Guildford. The cross-reactivity of this antiserum at $50 \%$ displacement was: progesterone, 100\%; 20 $\alpha$-hydroxypregn-4-en-3-one, 2.5\%; 20 $\beta$-hydroxypregn-4-en-3-one, $1.0 \%$; 11-deoxycorticosterone, $0.9 \%$; corticosterone, $0.8 \%$; $17 \alpha$-hydroxyprogesterone, $0.3 \%$; cortisol, $0.01 \%$; testosterone, $0.01 \%$; oestradiol- $17 \beta, 0.01 \%$. The intra- and interassay coefficients of variation were 7 and $15 \%$ respectively and the sensitivity of the assay was 0.022 pmol per assay tube. In each assay, allowance was made for extraction efficiency (usually $>90 \%$ ) by extracting and assaying a standard solution of progesterone in culture medium.

Progesterone production was calculated following correction for progesterone values obtained for non-incubated samples of cell suspension. Levels of significance for differences in 
progesterone estimates between sets of incubated samples were calculated using Student's $t$ test for unpaired values.

\section{Results}

Text-figure 1 shows the effect of hCG on progesterone production by dispersed luteal cells from guinea-pigs on Day 12 of the oestrous cycle. The relationship between hCG concentration and progesterone production was similar for a number of cell suspensions prepared at different stages of the oestrous cycle: the concentrations of hCG required to elicit $50 \%$ of the maximum response were $7,1,3,6,4,2$ and 5 milliunits $/ \mathrm{ml}$ for the particular experiments performed with cells prepared on Days 3, 5, 7, 9,10,12 and 13 of the cycle respectively. There was therefore no marked loss of sensitivity to hCG with increasing luteal age. Attempts to produce a cell suspension preparation from Day 15 corpora lutea were unsuccessful, presumably because of advanced luteolysis.

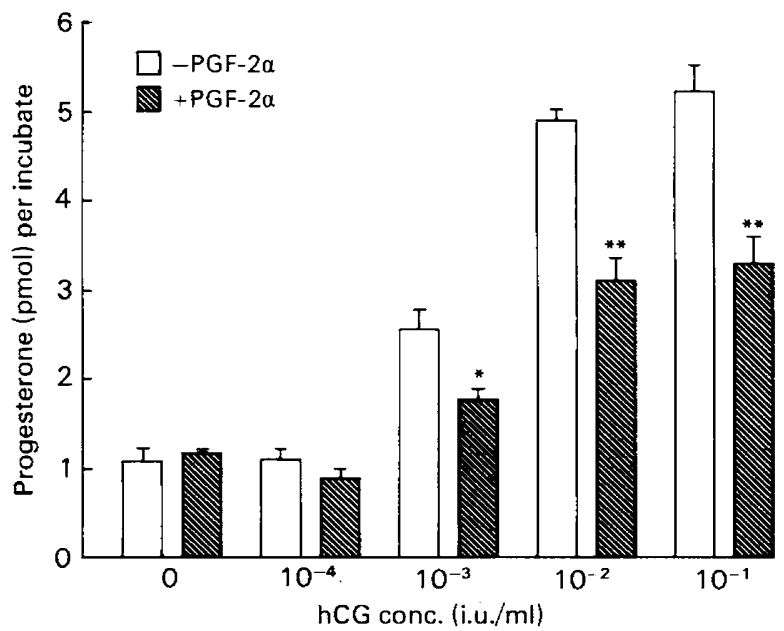

Text-fig. 1. Effect of PGF-2 $\alpha(1 \mu \mathrm{mol} / \mathrm{l})$ on hCG-stimulated progesterone production by dispersed cells from guinea-pig corpora lutea on Day 12 of the oestrous cycle. Luteal cells were incubated for $2 \mathrm{~h}$. Mean values (with s.e.m.) refer to estimates on quadruplicate incubations. ${ }^{*} P$ $<0.02,{ }^{* *} P<0.001$ compared with value for incubation without PGF-2 $\alpha$.

The effect of direct addition of PGF-2 $\alpha(1 \mu \mathrm{mol} / \mathrm{l})$ to dispersed luteal cells from 12-day old corpora lutea is also illustrated in Text-fig. 1. PGF- $2 \alpha$ alone caused no significant change in progesterone production (this was also true for other luteal ages studied). However, PGF-2 $\alpha$ caused a marked inhibition of hCG-stimulated progesterone production which was significant for each stimulatory concentration of hCG used. A time-course study (data not shown) suggested that the effect of PGF-2 $\alpha$ was to reduce the rate of progesterone production (roughly constant in the presence of hCG, $1 \times 10^{-2} \mathrm{i} . \mathrm{u} . / \mathrm{ml}$, alone) to a lower value maintained throughout the $2 \mathrm{~h}$ incubation period.

The extent of inhibition of hCG-stimulated progesterone production by PGF- $2 \alpha(1 \mu \mathrm{mol} / \mathrm{l})$ at various stages of the oestrous cycle is shown in Table 1 . The concentration of hCG used to make these comparisons $\left(1 \times 10^{-2} \mathrm{i} . \mathrm{u} . / \mathrm{ml}\right)$ was specifically chosen to give a clear response (more than $50 \%$ of maximum) without going beyond the concentration sufficient to elicit a maximum response. Gonadotrophin-stimulated progesterone production by luteal cells from newly formed 
corpora lutea (Days 3 and 5) was not inhibited significantly by PGF-2 $\alpha$. However, progesterone formation by preparations from older corpora lutea (Days 7, 9, 10,12 and 13) was markedly diminished in the presence of the prostaglandin.

Table 1. The effect of PGF- $2 \alpha$ on hCG-stimulated progesterone production by luteal cells from guinea-pigs at various stages of the oestrous cycle

\begin{tabular}{ccc}
\hline $\begin{array}{c}\text { hCG-stimulated progesterone } \\
\text { productiont in the presence } \\
\text { of PGF- } 2 \alpha(1 \mu \mathrm{mol} / \mathrm{l}) \text { as } \%\end{array}$ & $\begin{array}{c}\text { Significancet of } \\
\text { inhibitory action } \\
\text { of PGF-2 } \alpha\end{array}$ \\
of value in absence of PGF-2 $\alpha$ & $\begin{array}{c}\text { N.S. } \\
\text { of }\end{array}$ & N.S. \\
\hline 3 & $101.5 \pm 14.2$ & $P<0.05$ \\
5 & $84.4 \pm 5.0$ & $P<0.01$ \\
7 & $52.5 \pm 9.8$ & $P<0.001$ \\
9 & $48.7 \pm 10.9$ & $P<0.001$ \\
10 & $52.0 \pm 5.3$ & $P<0.01$ \\
12 & $51.5 \pm 7.0$ & \\
\hline
\end{tabular}

* For each day of cycle, results were obtained for one cell suspension prepared from 6-8 corpora lutea of 2 guinea-pigs.

+ Progesterone produced in the presence of hCG $\left(1 \times 10^{-2}\right.$ i.u./ml) minus basal production. Mean values ( \pm s.e.m.) refer to estimates on quadruplicate incubations. Variation (s.e.m.) between replicate incubations in the absence of PGF-2 $\alpha$ was $6.9,5.4,11.5$, $6 \cdot 5,6 \cdot 8,3.0$ and $1.6 \%$ for Days $3,5,7,9,10,12$ and 13 respectively.

$\ddagger$ Calculated for differences between values for hCG-stimulated progesterone production in the presence and absence of PGF-2a N.S. $=$ not significant.

\section{Discussion}

The present studies demonstrate that dispersed guinea-pig luteal cells respond in a dose-dependent manner to hCG by increasing progesterone production. It is assumed that the response to hCG mimics the action of LH since both hormones have been shown to interact with the same receptor population (Papaionannou \& Gospodarowicz, 1975).

The present report also establishes that the dispersed luteal cell system, prepared at particular stages of the oestrous cycle, may be used to study variations in the responsiveness to hormones throughout most of the natural life-span of the corpora lutea in non-pregnant cycles. Using this approach, it was evident that the sensitivity to gonadotrophin (in terms of the concentration of hCG required for $50 \%$ of the maximum response in vitro) remained quite stable (within a $\log$ (dose) unit) during a major part of the life of the guinea-pig corpus luteum.

The effects of PGF- $2 \alpha$ were investigated using a concentration $(1 \mu \mathrm{mol} / \mathrm{l})$ which was 5-6-fold greater than that observed for utero-ovarian vein blood on Day 15 of the oestrous cycle (Blatchley, Donovan, Horton \& Poyser, 1972). This concentration of PGF-2 $\alpha$ inhibits progesterone production by rat luteal cells (Thomas, Dorflinger \& Behrman, 1978). The finding that this concentration of PGF- $2 \alpha$ partly inhibited gonadotrophin-stimulated progesterone production by guinea-pig luteal cells is in agreement with observed inhibitory effects of this prostaglandin on the production of progesterone by guinea-pig corpora lutea in vivo (Dwyer \& Church, 1979). Present observations are also in agreement with similar direct effects of PGF-2 $\alpha$ on dispersed luteal cells (Thomas et al., 1978; Hall \& Robinson, 1979) and luteal explants (Lahav, Freud \& Lindner, 1976; Khan et al., 1979) of the rat, and superfused preparations from pig corpora lutea (Watson \& Maule-Walker, 1977). The observed lack of inhibition of basal 
progesterone production in the presence of PGF-2 $\alpha$ (also noted for rat luteal cells by Thomas $e t$ al., 1978) suggests that prostaglandin specifically inhibits gonadotrophin-stimulated steroid production. Such an inhibitory effect demonstrated in vitro clearly indicates that the luteolytic effect of PGF- $2 \alpha$ in the guinea-pig is mediated, at least in part, at the level of the individual luteal cell. This view is further supported by evidence of an absence of acute alteration in ovarian blood flow following administration of a luteolytic dose of PGF- $2 \alpha$ to guinea-pigs (Wehrenberg, Dierschke \& Wolf, 1979).

The observation that hCG-stimulated progesterone production by cells from newly formed corpora lutea (Days 3 and 5) was resistant to the inhibitory action of PGF-2 $\alpha$ provides confirmation of a previous report which describes a refractory period in vivo for PGF- $2 \alpha$ action on luteal volume in guinea-pigs (Tso \& Tam, 1977). A similar onset of responsiveness to PGF- $2 \alpha$ measured in vivo and in vitro has also been observed for corpora lutea of rats pretreated with PMSG (Khan et al., 1979). It remains to be established whether the delayed onset of responsiveness to PGF- $2 \alpha$ is associated with changes in PGF- $2 \alpha$ receptors in the corpus luteum. Although a gradual increase in PGF-2 $\alpha$ receptors with luteal age has been demonstrated for bovine corpora lutea (Rao, Estergreen, Carman \& Moss, 1979), the binding capacity and affinity of PGF-2 $\alpha$ receptors appeared to be similar at all stages of pseudopregnancy in the rat, despite changes in susceptibility to the prostaglandin (Wright, Pang \& Behrman, 1980). The biochemical events between prostaglandin reception and inhibition of adenylate cyclase (observed for rat corpora lutea by Thomas et al., 1978) may also be subject to change during maturation of the corpus luteum.

In summary, it would appear that the luteolytic action of PGF-2 $\alpha$ in the guinea-pig is manifest in vitro in terms of a rapid inhibitory effect on gonadotrophin-stimulated progesterone production. Responsiveness, acquired by Day 7 of the oestrous cycle, prepares the luteal cells for reception of the luteolytic signal provided by the uterine release of PGF- $2 \alpha$ beginning on Day 11 in the non-pregnant cycle (Blatchley et al., 1972).

\section{References}

Blatchley, F.R. \& Donovan, B.T. (1972) The effect of prostaglandin F-2 $\alpha$ and prostaglandin E-2 upon luteal function and ovulation in the guinea-pig. $J$. Endocr. 53, 493-501.

Blatchley, F.R., Donovan, B.T., Horton, E.W. \& Poyser, N.L. (1972) The release of prostaglandins and progestin into the utero-ovarian venous blood of guinea-pigs during the oestrous cycle and following oestrogen treatment. J. Physiol., Lond. 223, 6988.

Dwyer, R.J. \& Church, R.B. (1979) Effect of prostaglandin F-2 $\alpha$ on plasma levels of progesterone and pregnenolone in the hysterectomized guinea-pig. $J$. Reprod. Fert. 56, 81-84.

Hall, A.K. \& Robinson, J. (1979) Functional luteolysis in the pseudopregnant rat; effect of prostaglandin F-2 $\alpha$ and 16-aryloxyprostaglandin F-2 $\alpha$ in vitro. $J$. Endocr. 81, 157-165.

Karim, S.M.M. \& Hillier, K. (1979) Prostaglandins in the control of animal and human reproduction. $B r$. med. Bull. 35, 173-180.

Khan, M.I., Rosberg, S., Lahav, M., Lamprecht, S.A., Selstam, G., Herlitz, H. \& Ahren, K. (1979) Studies on the mechanism of action of the inhibitory effect of prostaglandin F-2 $\alpha$ on cyclic AMP accumulation in rat corpora lutea of various ages. Biol. Reprod. 21, 1175-1183.
Lahav, M., Freud, A. \& Lindner, H.R. (1976) Abrogation by prostaglandin F-2 $\alpha$ of LH-stimulated cyclic AMP accumulation in isolated rat corpora lutea of pregnancy. Biochem. Biophys. Res. Commun. 68, 1294-1300.

Papaionannou, S. \& Gospodarowicz, D. (1975) Comparison of the binding of human chorionic gonadotropin to isolated bovine luteal cells and bovine luteal plasma membranes. Endocrinology 97, 114124.

Peddie, M.J. (1980) Follicular development in the adult guinea-pig and responses to human chorionic gonadotrophin. J. Endocr. 85, 9-16.

Poyser, N.L. (1976) Prostaglandin F-2 $\alpha$ is the uterine luteolytic hormone in the guinea-pig: the evidence reviewed. Adv. Prostaglandin Thromboxane Res. 2, 633-643.

Rao, Ch.V., Estergreen, V.L., Carman, F.R. \& Moss, G.E. (1979) Receptors for gonadotrophin and prostaglandin F- $2 \alpha$ in bovine corpora lutea of early, mid and late luteal phase. Acta endocr., Copenh. 91, 529-537.

Richardson, M.C. \& Masson, G.M. (1980) Progesterone production by dispersed cells from human corpus luteum: stimulation by gonadotrophins and prostaglandin F-2 $\alpha$; lack of response to adrenaline and isoprenaline. J. Endocr. 87, 247-254. 
Richardson, M.C. \& Peddie, M.J. (1980) Progesterone production by a dispersed cell preparation from guinea-pig corpora lutea: progressive onset of an inhibitory action of prostaglandin F-2 $\alpha$ during the life of the corpus luteum. J. Endocr. 87, 25P-26P.

Tennant, J.R. (1964) Evaluation of the trypan blue technique for the determination of cell viability. Transplantation 2, 685-694.

Thomas, J.-P., Dorflinger, L.J. \& Behrman, H.R. (1978) Mechanism of the rapid antigonadotropic action of prostaglandins in cultured luteal cells. Proc. natn. Acad. Sci. U.S.A. 75, 1344-1348.

Tso, E.C.-F. \& Tam, W.H. (1977) The effect of continuous treatment with prostaglandin $\mathrm{F}-2 \alpha$ on oestrous cycle length and corpus luteum regression in hysterectomized guinea-pigs. J. Reprod. Fert. 50, 335-336.
Watson, J. \& Maule-Walker, F.M. (1977) Effect of prostaglandin $\mathrm{F}-2 \alpha$ and uterine extracts on progesterone secretion in vitro by superfused pig corpora lutea. J. Reprod. Fert. 51, 393-398.

Wehrenberg, W.B., Dierschke, D.J. \& Wolf, R.C. (1979) The effect of prostaglandin F-2 $\alpha$ on ovarian blood flow and progesterone concentrations in cyclic guinea-pigs. Biol. Reprod. 21, 187-191.

Wright, K., Pang, C.Y. \& Behrman, H.R. (1980) Luteal membrane binding of prostaglandin F-2 $\alpha$ and sensitivity of corpora lutea to prostaglandin F-2 $\alpha$ induced luteolysis in pseudopregnant rats. Endocrinology 106, 1333-1337.

Received 6 November 1981 